\title{
Spawning Migration of Telemetered Striped Bass in the Roanoke River, North Carolina
}

\author{
John T. Carmichael, ${ }^{1}$ Steven L. Haeseker, ${ }^{2}$ And Joseph E. Hightower* \\ U.S. Geological Survey, Biological Resources Division \\ North Carolina Cooperative Fish and Wildlife Research Unit \\ Box 7617, North Carolina State University, Raleigh, North Carolina 27695-7617, USA
}

\begin{abstract}
The spring spawning migration is a key period for effective management of anadromous populations of striped bass Morone saxatilis. Information on migratory behavior is needed in order to develop appropriate harvest regulations and to conduct effective surveys while fish are on the spawning grounds. We used ultrasonic telemetry to estimate the timing and duration of the upriver spawning migration for the Roanoke River, North Carolina, population and to evaluate whether a short-term fluctuation in temperature or flow would alter the distribution of telemetered fish on the spawning grounds. Seventy-eight fish implanted with transmitters were released during 1993 and 1994. Twenty-nine telemetered fish migrated upriver in 1994, and 14 telemetered fish entered the river in 1995. Migration of telemetered fish began in mid- to late April when water temperatures in the lower river reached $17-18^{\circ} \mathrm{C}$. Males began their spawning migration significantly earlier than females in 1994; the difference was not significant in 1995. The 165-km upriver migration took about a week, as did the downriver migration after the spawning season. In 1994 and 1995 respectively, males remained on the spawning grounds for averages of 22 and $21 \mathrm{~d}$, females for 8 and $11 \mathrm{~d}$. Because of shorter residency times only about half the telemetered females were on the spawning grounds at any one time during the peak of the spawning season. Striped bass remained on the spawning grounds during a short-term temperature decrease of about $4^{\circ} \mathrm{C}$ (over 5 d) and an increase in flow from about 190 to $390 \mathrm{~m}^{3} / \mathrm{s}$ (over $1 \mathrm{~d}$ ).
\end{abstract}

Anadromous populations of striped bass Morone saxatilis are found within several North Carolina river systems. The largest population is in the Roanoke River and its estuary, Albemarle Sound (Smith 1907; Trent and Hassler 1968; Manooch and Rulifson 1989). Striped bass of the Roanoke River population spend much of the year within Albemarle Sound and adjoining waters, migrating up the Roanoke River in spring to spawn near Weldon, North Carolina (Figure 1) (Smith 1907; Trent and Hassler 1968; Haeseker et al. 1996). This population historically supported important commercial and recreational fisheries within Albemarle Sound and the Roanoke River, but both commercial and recreational landings declined substantially from the mid-1970s through the late 1980 s (USFWS 1992). The decline in landings corresponded to a decline in population size (USFWS 1992), which has been attributed to overfishing and reduced recruitment associated with changes in Roanoke River flow during the spawning season

\footnotetext{
* Corresponding author: jhightower@ncsu.edu

${ }^{1}$ Present address: North Carolina Department of Environment and Natural Resources, Division of Marine Fisheries, Morehead City, North Carolina 28557, USA.

2 Present address: Department of Fisheries and Wildlife, 13 Natural Resources Building, Michigan State University, East Lansing, Michigan 48824-1222, USA.
}

(Rulifson and Manooch 1990a; Dorazio 1995). Management efforts to rebuild the stock have focused on limiting harvest and increasing recruitment.

Previous studies have provided much information about the general patterns of migration and spawning of Roanoke River striped bass. The upriver migration generally begins in late March and ends in early May (Trent and Hassler 1968). Females tend to migrate about 2 weeks later than the males (Hassler et al. 1981). Based on egg production studies, spawning occurs from about midApril to mid-June, typically peaking in mid-May (Hassler et al. 1981; Rulifson 1992). Spawning generally begins when water temperatures on the spawning grounds reach about $18^{\circ} \mathrm{C}$ (Rulifson 1991).

This information about population-level patterns of migration was obtained by monitoring various commercial and recreational fisheries and by conducting conventional tagging studies and surveys. An objective of our study was to obtain detailed information about the movements of individual fish during the spawning season. We used telemetry methods to estimate the timing and rate of the upstream and downstream migrations, the amount of time individual male and female fish spent on the spawning grounds, and the move- 


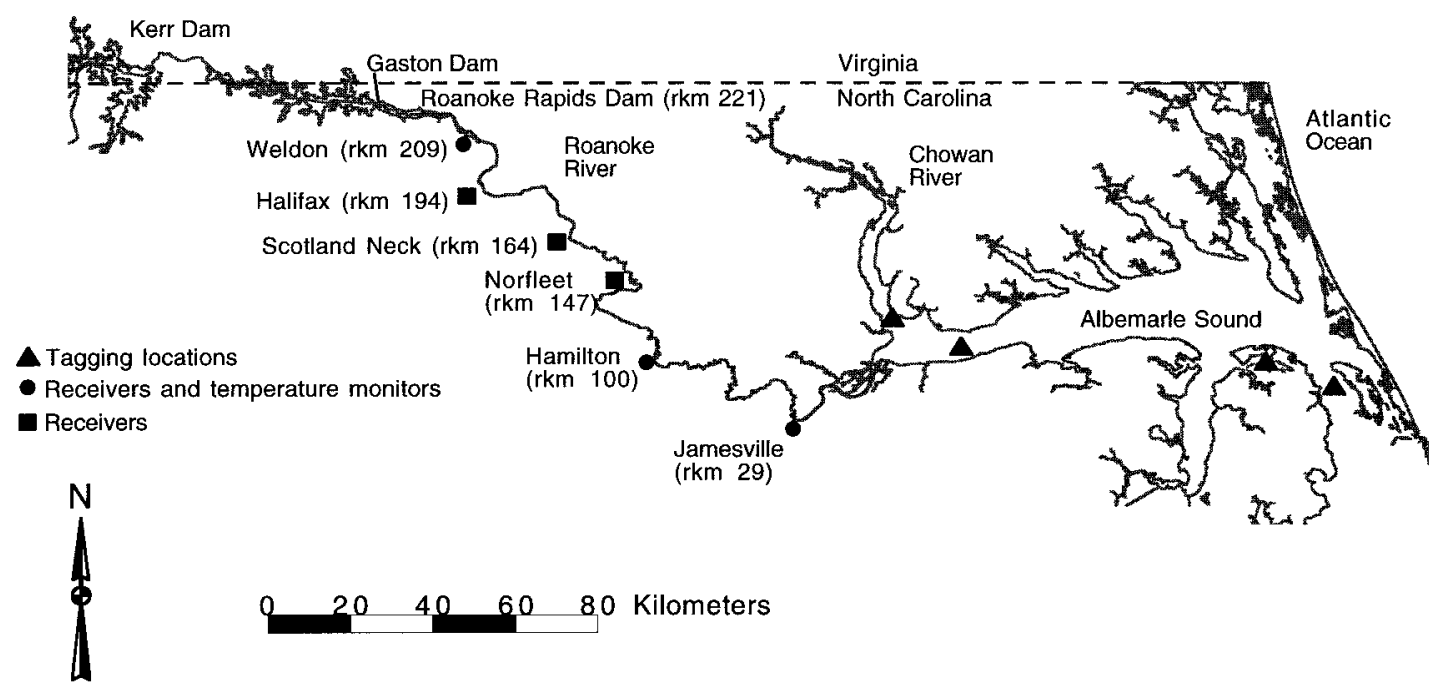

FiguRE 1.-The Roanoke River-Albemarle Sound system in North Carolina, showing temperature monitors during spring 1994. Distances from the sound are given as river kilometers (rkm).

ments those fish made on the spawning grounds. Differences between sexes in migratory patterns and time spent on the spawning grounds produce differences in vulnerability to harvest and to surveys, such as the electrofishing survey conducted annually on the spawning grounds (Kornegay and Nelson 1995; Kornegay 1997). Using telemetry methods to evaluate migration removes any bias due to differences in vulnerability to conventional sampling.

Our second objective was to examine the response of Roanoke River striped bass to changes in river flow and temperature. Earlier work had established that recruitment is affected by the pattern of flow in the lower Roanoke River during spring (Hassler et al. 1981; Rulifson and Manooch 1990a). Flow affects the timing and location of spawning, suspension of the semibuoyant eggs until hatching occurs, and transport of larvae to critical nursery areas (Hassler et al. 1981; Manooch and Rulifson 1989; Henry and Taylor 1991; Rulifson 1991, 1992; Rulifson et al. 1992). Changes in flow can affect spawning activity by causing temperatures on the spawning grounds to drop below $18^{\circ} \mathrm{C}$ (Hassler et al. 1981; Manooch and $\mathrm{Ru}-$ lifson 1989; Rulifson 1991). For example, a sharp decrease in spawning activity attributed to increased flow was observed in early May of 1989, when flow increased from about 170 to $566 \mathrm{~m}^{3} / \mathrm{s}$ and downstream water temperatures decreased from about 18 to $16^{\circ} \mathrm{C}$ (Rulifson and Manooch 1990b). This decrease in downstream temperature resulted in about a 2 -week period with no spawn- ing activity (Rulifson and Manooch 1990b). In addition, Manooch and Rulifson (1989) and Kornegay (1997) have suggested that sudden flow or temperature changes might cause spawning fish to leave the spawning grounds. To examine the issue of sudden change, we worked with the U.S. Army Corps of Engineers in 1994 to introduce a shortterm change in flow during the period when telemetered striped bass were present on the spawning grounds.

\section{Study Site}

The lower Roanoke River flows freely for 221 $\mathrm{km}$ between the Roanoke Rapids Lake dam and the mouth at the western end of Albemarle Sound (Figure 1). Average annual discharge is about 240 $\mathrm{m}^{3} / \mathrm{s}$ (Giese et al. 1985). The river drops about 15 $\mathrm{m}$ in $11 \mathrm{~km}$ at the fall line between the Roanoke Rapids Lake dam and Weldon. Through this area, the river bottom is mostly rock, and flow is channeled around many islands and boulders. After passing the last falls at Weldon, the river flows through the Coastal Plain with a single main stem about $100 \mathrm{~m}$ wide; the average drop is about 0.1 $\mathrm{m} / \mathrm{km}$.

Flow in the lower Roanoke River is controlled by the John H. Kerr, Gaston, and Roanoke Rapids Lake dams, which were built between 1950 and 1963 to provide hydropower and flood control. Kerr Reservoir has the largest storage capacity of the three impoundments and influences operations of Lake Gaston and Roanoke Rapids Lake. Discharge from the system of dams, which accounts 
for about $87 \%$ of the downstream flow (Giese et al. 1985), influences water depth and current velocity in the lower river. Maximum river depth typically ranges from 3 to $6 \mathrm{~m}$, but it can exceed $12 \mathrm{~m}$ in upriver areas during high spring flows or other periods of prolonged high discharge. Current velocity is typically around $0.5 \mathrm{~m} / \mathrm{s}$, but it can surpass $1.0 \mathrm{~m} / \mathrm{s}$ during high flow.

Prior to the construction of dams, the spawning migration of Roanoke River striped bass reportedly extended above the fall line at Weldon to Clarksville and Danville, Virginia (Jenkins and Burkhead 1994; Earley and Dossett 1996). However, the importance of habitats above the fall line is unclear, both because downstream fisheries long were intensive (Stevenson 1897) and because a main-stem dam for hydropower production was constructed around 1900 near the site of the current Roanoke Rapids dam (Coe 1964). Since 1900, the area between Weldon and Halifax has generally been considered the primary spawning grounds (Smith 1907; Hassler et al. 1981; Rulifson 1992). During years of prolonged low flow, spawning can occur further downriver near the towns of Halifax and Hamilton (Manooch and Rulifson 1989). Striped bass often migrate above the lowermost falls at Weldon during periods of high flow, but they tend to move downriver below the first set of falls as flow decreases (Smith 1907; Kornegay and Nelson 1995).

To the extent possible, flow regulation during the striped bass spawning season is based on a regime negotiated in 1988 between the U.S. Army Corps of Engineers, North Carolina Power, and the North Carolina Wildlife Resources Commission. The regime consists of daily minimum and maximum flows and a maximum rate of change for April 1 through June 15. For example, target flows during May are about $170 \mathrm{~m}^{3} / \mathrm{s}$, with an hourly variation of no more than $42 \mathrm{~m}^{3} / \mathrm{s}$. The intent of the regime is to provide moderate sustained flows during the spawning season. Strong year-classes have tended to occur during years of low to moderate river flows during May (Hassler et al. 1981; Rulifson and Manooch 1990a).

\section{Methods}

We used ultrasonic telemetry techniques to study the migration and spawning ground movements of Roanoke River striped bass. Transmitters were surgically implanted according to procedures used in previous telemetry studies (Hart and Summerfelt 1975; Hocutt et al. 1990) and based on results from a 1993 pilot study in which we re- leased 37 fish (Carmichael 1995; Haeseker et al. 1996). The transmitters (VEMCO Ltd., Nova Scotia) operated on five frequencies $(50.00,54.00$, $60.00,63.66$, and $65.54 \mathrm{kHz}$ ); unique pulse periods within each frequency allowed identification of individual fish. The cylindrical transmitters were 90 $\mathrm{mm}$ long and $16 \mathrm{~mm}$ in diameter, weighed $33.7 \mathrm{~g}$, and had a volume of $19 \mathrm{~mL}$. For each fish released, we measured total length $(\mathrm{mm})$ and weight $(\mathrm{g})$, and we collected scales for age determination. A complete description of the surgical techniques used to implant the transmitters was provided by Haeseker et al. (1996).

Striped bass collected in the Roanoke River during a 1993 pilot study exhibited strong downriver flight responses following release (Carmichael 1995). Similar behavior has been reported in other telemetry studies involving striped bass, American shad Alosa sapidissima, shortnose sturgeon Acipenser brevirostrum, and chinook salmon Oncorhynchus tshwaytscha (Gray and Haynes 1979; Hall et al. 1991; Moser and Ross 1995). Hassler et al. (1981) also observed downriver flight responses by striped bass after conventional tagging, so the effect is not due strictly to surgery. Therefore, to minimze the effect of capture and handling on movements during the spawning season, we collected the fish for the 1994 spawning season in Albemarle and Croatan sounds between December 1993 and March 1994. To insure that only mature fish were tagged, we set a minimum tagging size of $550 \mathrm{~mm}$ for females (age 4) and $500 \mathrm{~mm}$ for males (age 3) (Merriman 1941; Hassler et al. 1981; Nelson 1991; Olsen and Rulifson 1992).

Sonically tagged fish were located during AprilJune 1994 by means of six fixed receiving stations and manual tracking by boat (Figure 1). In 1995, limited monitoring was done at the Jamesville and Halifax stations to detect those fish that still had working transmitters. The receiving stations provided information about the timing and rate of migration throughout the river; manual searches were done primarily on the spawning grounds. The lowermost fixed receiving station at river kilometer (rkm) 29 above Albemarle Sound was upriver of several known migration routes that bypass the main river channel; the uppermost station was on the spawning grounds at Weldon (rkm 209), just below the fall line. We used VEMCO VR-20 and Sonotronics (Sonotronics Inc., Tucson, Arizona) USR-90 scanning receivers for data logging, and a Sonotronics USR-5B digital receiver with a directional hydrophone for manual tracking. During 1994, tagged fish were located at least once 
each day and during several nights once they reached the spawning grounds. During most of the spawning season, searches were confined to the area below the last falls at Weldon because the water level did not allow safe navigation of upriver areas.

Upon locating a fish, we recorded the transmitter frequency and pulse interval, time, date, location, water depth, and water temperature $1 \mathrm{~m}$ below the surface. Water temperature associated with fish passing a receiving station was estimated from the nearest temperature monitor (see below). Migratory patterns were assumed to be related to spawning, even though spawning could not be confirmed for individual telemetered fish. While on the spawing grounds, telemetered fish frequently were located close to spawning fish.

In migration studies, it is important to define criteria for the endpoints of migratory movements (White and Garrott 1990). We used the first detection of a fish at the lowermost station to indicate the start of upriver migration. When a fish passed the Halifax station, we considered it to be on the spawning grounds. The beginning of downriver migration was indicated by a fish passing the Halifax station without a subsequent return to the Weldon area. The end of downriver migration was determined by detection at the lowermost station.

We used Satterthwaite's $t$-test (Koopmans 1981) to test for differences in the timing and rate of migration between sexes or years when variances differed significantly; otherwise, a standard $t$-test was used. We used linear regression to determine if the time on the spawning grounds was related to the date of arrival. All analyses were based on a $5 \%$ significance level.

We measured hourly water temperatures at Weldon, Hamilton, and Jamesville using submersible loggers (HOBO TEMP, Onset Inc., Pokaset, Massachusetts). North Carolina Power provided hourly water temperature data for the tailrace of the Roanoke Rapids dam. Mean daily air temperature at Roanoke Rapids was obtained from the North Carolina State Climatologist Office. We obtained flow data for the U.S. Geological Survey (USGS) gaging station at Roanoke Rapids (USGS gage 02080500), $4.5 \mathrm{~km}$ below the dam. To evaluate the effect of a change in flow on water temperature and the distribution of striped bass, we worked cooperatively with the U.S. Army Corps of Engineers to produce a rapid change in flow while several telemetered fish (seven males and three females) were on the spawning grounds. Flow was increased rapidly on May 4 from 190 to $390 \mathrm{~m}^{3 /}$ $\mathrm{s}$ and held at that level for $24 \mathrm{~h}$.

To estimate spawning activity, we counted striped bass spawning acts or "fights" at the water's surface during May 2-30, 1994. Ross et al. (1994) used a similar technique to estimate spawning activity of American shad. The count was taken from shore at Weldon, and the value was the number of fights observed in a 5-min period near dusk (about 1900 hours).

\section{Results}

Twenty-seven telemetered striped bass entered the Roanoke River from Albemarle Sound during the 1994 spawning migration. This number included 25 of 41 fish released prior to the 1994 spawning season and 2 released during the 1993 pilot study. Fourteen females and nine males reached the spawning grounds, three fish migrated partially upriver before returning to Albemarle Sound, and one disappeared between the Norfleet and Scotland Neck stations (presumably it was harvested). Individual fish were located 10-50 times while in the river.

Fourteen telemetered fish entered the Roanoke River during the 1995 spawning season. Six females and five males reached the spawning grounds, two were not located after migrating upriver past Jamesville (presumably they were harvested or their tag batteries failed), and one was harvested by an angler who reported the tag. Twelve of the 14 fish also had completed the 1994 spawning migration, one had made a partial migration in 1994, and one had not been located during either spring or summer 1994.

Telemetered male and female striped bass typically began upriver migration in mid- to late April, although there was considerable variation among individuals (Table 1; Figure 2). Males began migration significantly earlier than females during 1994; no difference was detected in 1995, although sample sizes were small. Telemetered females migrated significantly earlier in 1995 than in 1994. In both years, males and females completed the $165-\mathrm{km}$ upriver migration from Jamesville to Halifax in about a week. For 1994, mean water temperatures were $17.3^{\circ} \mathrm{C}$ (range, 15.2$19.8^{\circ} \mathrm{C}$ ) when males passed the lowermost monitoring station and $17.6^{\circ} \mathrm{C}$ (range, $15.0-20.3^{\circ} \mathrm{C}$ ) when females did so at the start of migration. Mean water temperatures at Halifax were $17.1^{\circ} \mathrm{C}$ (range, $15.5-19.6^{\circ} \mathrm{C}$ ) and $18.8^{\circ} \mathrm{C}$ (range, $16.1-22.3^{\circ} \mathrm{C}$ ), respectively, when male and female striped bass reached the spawning grounds. 
TABLE 1.-Means \pm 1 SEs (in days) and sample sizes (number of fish, in parentheses) for the migration dates and duration shown by telemetered male and female striped bass in the Roanoke River in 1994 and 1995. Probabilities $(P)$ indicate the statistical differences between years (94 and 95) or sexes (males, M, and females, F).

\begin{tabular}{lrrr}
\hline \multicolumn{1}{c}{ Migration datum } & \multicolumn{1}{c}{ Males } \\
\cline { 2 - 4 } & \multicolumn{1}{c}{1994} & 1995 & $P(94-95)$ \\
\hline Date & & & \\
Begin migration & Apr $20 \pm 2.0(7)$ & Apr $17 \pm 2.7(5)$ & 0.353 \\
Reach spawning & Apr $28 \pm 1.9(9)$ & Apr $24 \pm 2.5(5)$ & 0.264 \\
Depart spawning & May $21 \pm 1.2(9)$ & May $16 \pm 2.6(5)$ & 0.127 \\
Leave river & May $27 \pm 2.0(7)$ & $7.7 \pm 1.6(5)$ & 0.033 \\
Duration (d) & & & 0.898 \\
$\quad$ Upriver migration & $7.5 \pm 1.6(7)$ & $2.8 \pm 1.1(4)$ & 0.013 \\
Downriver migration & $6.6 \pm 1.1(7)$ & $2.2 \pm 3.2(5)$ & 0.822 \\
Time on spawning grounds & $22.1 \pm 2.1(9)$ & $29.7 \pm 3.4(4)$ & 0.236 \\
Time in river & $36.9 \pm 3.4(5)$ & & \\
\hline
\end{tabular}

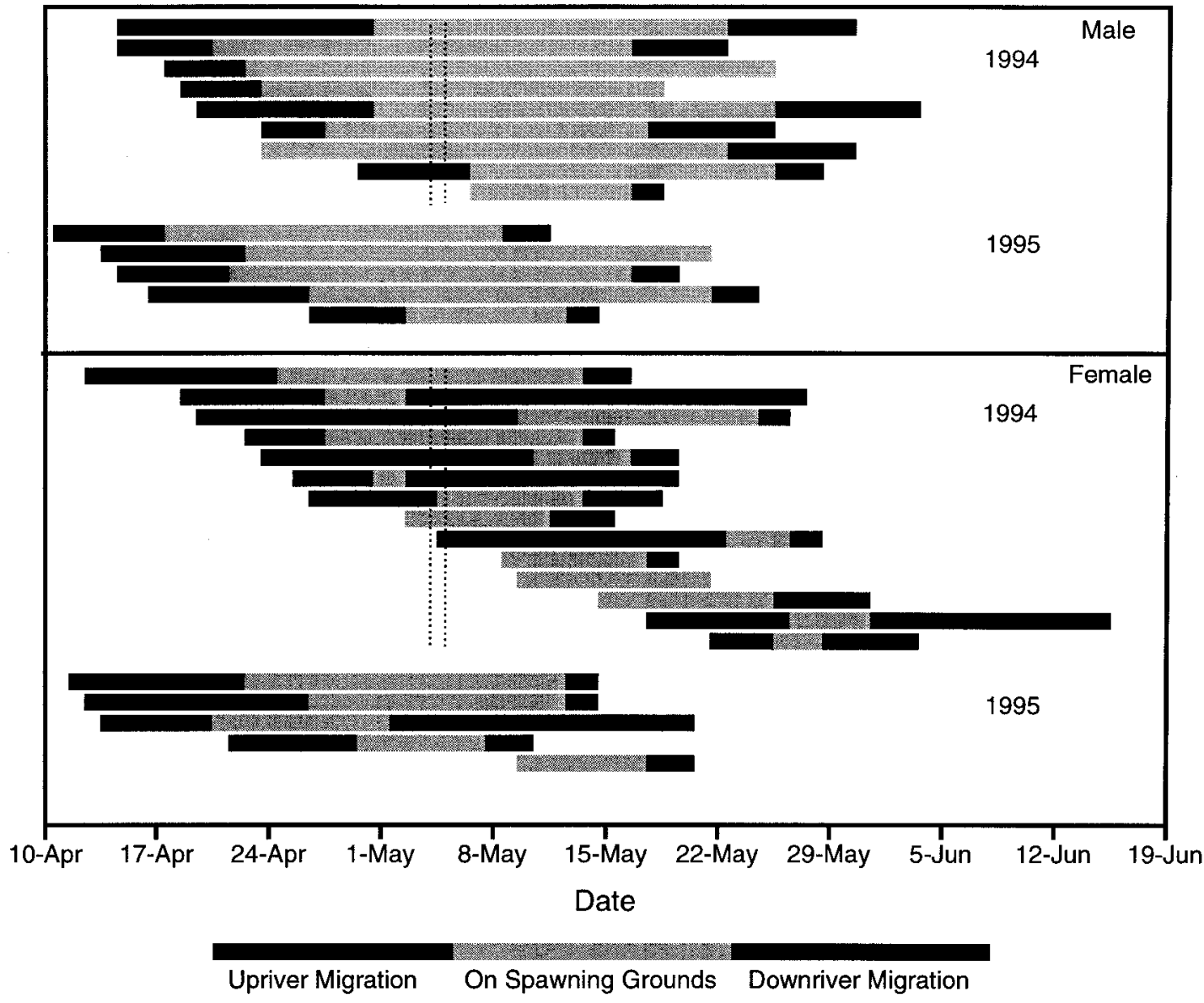

FIGURE 2.- Timing and duration of upriver and downriver migrations and spawning ground residency times for individual telemetered male and female striped bass during 1994 and 1995. Vertical reference lines indicate timing of the controlled flow experiment. 
TABLE 1.-Extended.

\begin{tabular}{|c|c|c|c|c|c|}
\hline \multirow[b]{2}{*}{ Migration datum } & \multicolumn{3}{|c|}{ Females } & \multicolumn{2}{|c|}{$P(\mathrm{M}-\mathrm{F})$} \\
\hline & 1994 & 1995 & $P(94-95)$ & 1994 & 1995 \\
\hline \multicolumn{6}{|l|}{ Date } \\
\hline Begin migration & Apr $29 \pm 3.9(10)$ & Apr $16 \pm 2.1(5)$ & 0.016 & 0.05 & 0.86 \\
\hline Reach spawning & May $9 \pm 2.8(14)$ & Apr $29 \pm 2.8(6)$ & 0.014 & 0.01 & 0.32 \\
\hline Depart spawning & May $17 \pm 2.4(14)$ & May $10 \pm 2.8(5)$ & 0.064 & 0.26 & 0.15 \\
\hline Leave river & May $24 \pm 2.6(13)$ & May $16 \pm 2.0(5)$ & 0.018 & 0.47 & 0.64 \\
\hline \multicolumn{6}{|l|}{ Duration (d) } \\
\hline Upriver migration & $10.6 \pm 1.8(10)$ & $11.5 \pm 1.8(5)$ & 0.757 & 0.23 & 0.12 \\
\hline Downriver migration & $7.1 \pm 2.0(13)$ & $6.0 \pm 2.0(5)$ & 0.784 & 0.87 & 0.44 \\
\hline Time on spawning grounds & $7.9 \pm 1.4(14)$ & $11.3 \pm 1.5(5)$ & 0.258 & $<0.01$ & 0.04 \\
\hline Time in river & $26.1 \pm 2.4(10)$ & $29.1 \pm 2.4(4)$ & 0.557 & 0.02 & 0.91 \\
\hline
\end{tabular}

The time telemetered fish remained on the spawning grounds was related both to sex and the time of arrival. Telemetered males remained on the spawning grounds significantly longer than females (Table 1). Males that arrived earlier stayed significantly longer $\left(r^{2}=0.66\right.$; Figure 3$)$. A similar trend was indicated for females, but the relationship was not significant $\left(r^{2}=0.27 ; P=\right.$ 0.06). Most telemetered fish left the spawning grounds in mid- to late May (Table 1; Figure 2), and the downriver migration took about a week for both sexes. For 1994, mean water temperatures at Halifax were $20.2^{\circ} \mathrm{C}$ (range, $18.7-22.3^{\circ} \mathrm{C}$ ) and $19.5^{\circ} \mathrm{C}$ (range, $18.2-21.1^{\circ} \mathrm{C}$ ), repectively, for male and female striped bass departing the spawning grounds.

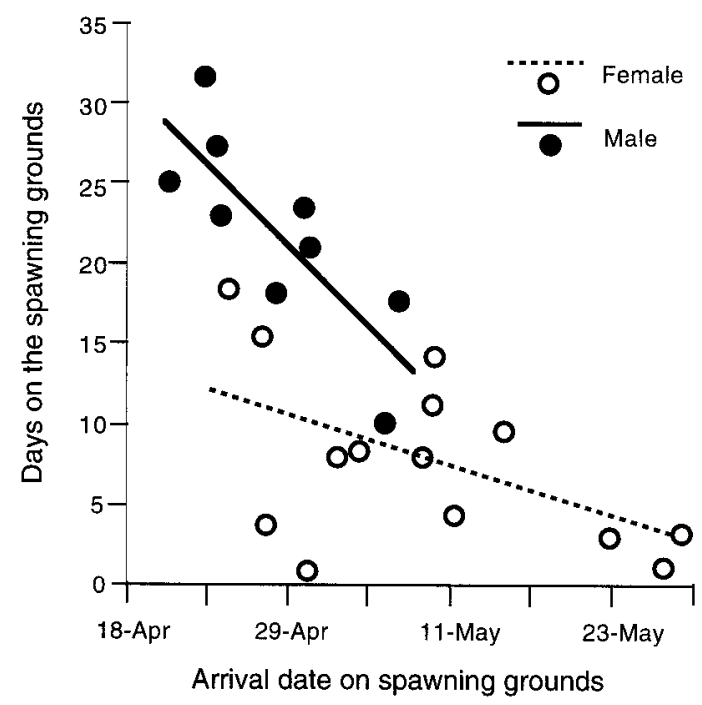

FIGURE 3.-Numbers of days that telemetered fish remained on the spawning grounds versus arrival date for male and female striped bass in 1994.
The proportion of telemetered striped bass of each sex on the spawning grounds was affected by differences in residency time and the timing of migration (Figure 4). All telemetered males that migrated upriver occurred together on the spawning grounds for 6-9 d. Because individual females spent less time on the spawning grounds and showed more variability in the timing of migration, the proportion of females was more variable and peaked at about 50\% in 1994 and 80\% in 1995 .

During 1994, we observed spawning activity when water temperatures were above $18^{\circ} \mathrm{C}$, particularly when temperatures were increasing (Figure 5). The changes in water temperature from day to day were similar for the reservoir discharge and the spawning grounds and, at the observed flow rates, appeared to be due largely to changes in air temperature (Figure 6). Of particular interest was a decrease in daily mean air temperature from 23.9 to $11.7^{\circ} \mathrm{C}$ during May $1-5$. There was a corresponding decrease in water temperature on the spawning grounds of $4.19^{\circ} \mathrm{C}$ over the period May $1-6$ (from 20.28 to $16.09^{\circ} \mathrm{C}$ ). No fish left the spawning grounds due to this decrease in temperature, although spawning activity halted (Figures $2,6)$. The experimental increase in flow during May 4-5 (from about 190 to $390 \mathrm{~m}^{3} / \mathrm{s}$ over $1 \mathrm{~d}$ ) did not noticeably affect water temperature (which was already decreasing due to low air temperatures), but did appear to reduce the diurnal fluctuation in spawning ground water temperature. No fish were observed leaving the spawning grounds due to the flow experiment, but one telemetered fish did move into a smaller tributary having lower current velocities.

\section{Discussion}

The migratory patterns for our telemetered fish were generally consistent with results of other 

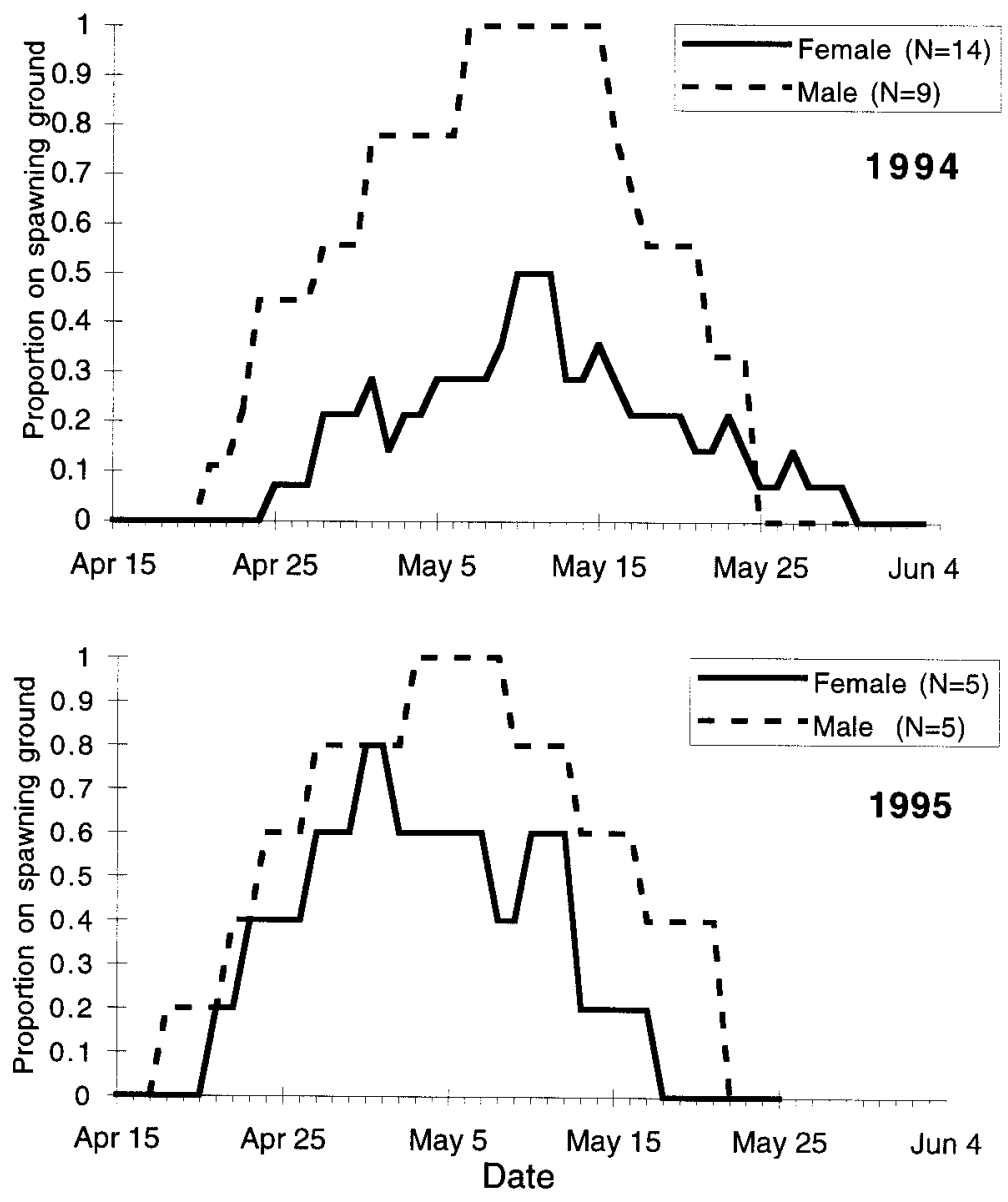

FIGURE 4.-Proportions of telemetered striped bass that migrated which were present on the spawning grounds versus date during spring 1994 and 1995.

studies. Trent and Hassler (1968) reported that striped bass begin to migrate upriver in late March. Male striped bass generally migrate through the Williamston area (rkm 48) between March 25 and April 20 (Trent and Hassler 1968). Most of our telemetered males migrated past the monitoring station at rkm 29 in mid- to late April. Our telemetered females generally passed the lowermost station between mid-April and mid-May, which is consistent with the interval of April 15-May 10 reported by Trent and Hassler (1968) for Williamston. Telemetered female striped bass were on the spawning grounds between late April and mid- to late May, which is consistent with other information regarding the timing of spawning activity. Based on egg production studies, most spawning occurs between mid-April and early June, the midpoint of spawning activity occurring near mid-May (Hassler et al. 1981; Rulifson 1991; Rulifson et al.
1993). Electrofishing surveys indicate that most striped bass leave the spawning grounds by the end of May (Kornegay and Nelson 1995; Kornegay 1997).

Our telemetry results for 1994 and other Roanoke River surveys (Trent and Hassler 1968; Hassler et al. 1981; Henry et al. 1992) indicate that male striped bass begin their spawning migration earlier than females. We observed a mean difference of $9 \mathrm{~d}$ in the start of migration, whereas Hassler et al. (1981) reported a difference of about 2 weeks. We did not detect a difference between sexes in the initiation of the spawning migration for 1995, although sample sizes were small because few fish still had working transmitters. Earlier spawning migrations by males has also been documented for Hudson River striped bass (McLaren et al. 1981) and several other anadromous species, including white perch Morone amer- 


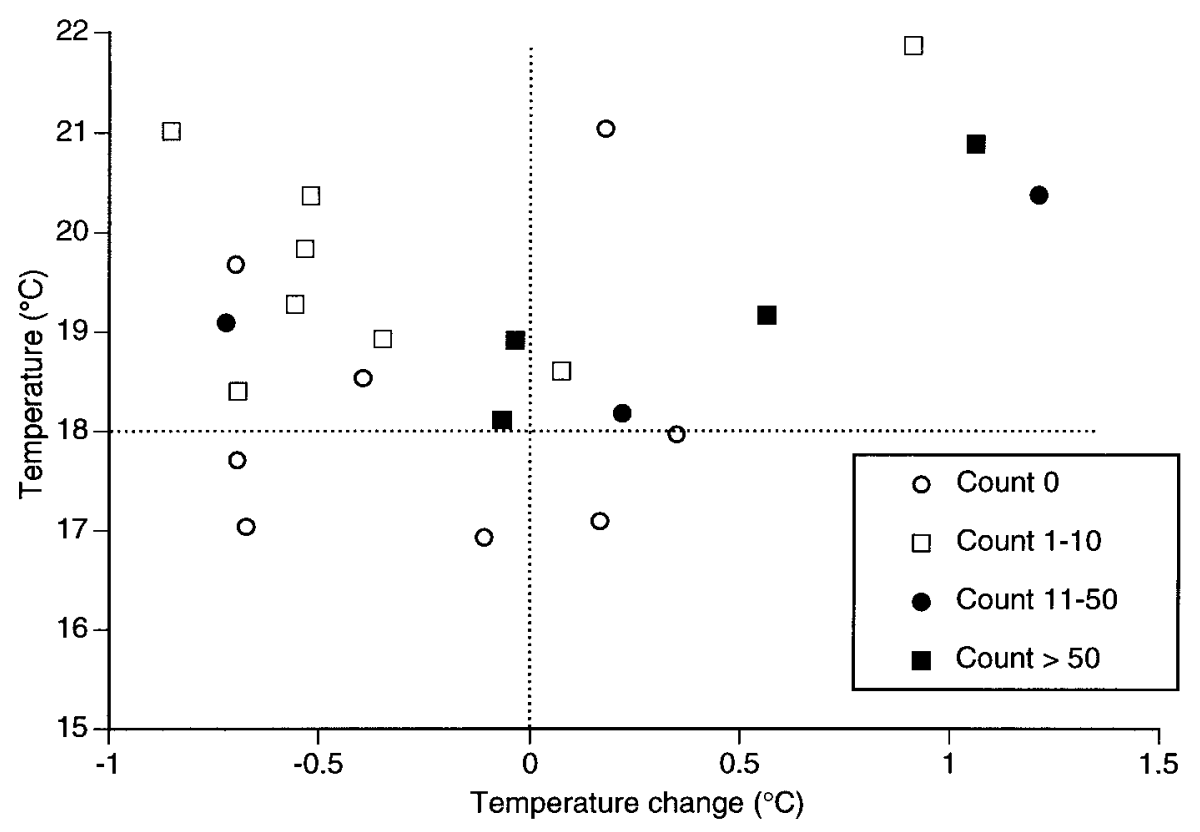

Figure 5.-Daily spawning fight counts (symbols) observed for different combinations of mean daily water temperature and change in mean daily water temperature on the spawning grounds, 1994 . Vertical line indicates a temperature change of $0^{\circ} \mathrm{C}$; horizontal line indicates $18^{\circ} \mathrm{C}$, the temperature that triggers spawning activity.

icana, American shad, blueback herring Alosa aestivalis, alewife Alosa pseudoharengus, Atlantic sturgeon Acipenser oxyrinchus, and Gulf sturgeon Acipenser oxyrinchus destoi (Mansueti 1961; Holland and Yelverton 1973; Chittenden 1975; Loesch and Lund 1977; Dovel and Berggren 1983; Gilbert 1992; Van Eenennaam et al. 1996).

In both 1994 and 1995, we found that telemetered male striped bass remained on the spawning grounds significantly longer than did females. Similar results have been reported for striped bass in California (Chadwick 1967) and in Chesapeake Bay (Hocutt et al. 1990). In another Chesapeake Bay telemetry study, R. V. Jesien and C. H. Hocutt (unpublished report to Maryland Department of Natural Resources) found no difference in residency time between males and females. Only limited conclusions can be drawn from the Chesapeake Bay studies, however, because the fish had already reached the spawning grounds before monitoring began. Male white bass Morone chrysops and blueback herring remain on the spawning grounds for an extended time, whereas females leave soon after spawning (Hasler et al. 1958; Loesch and Lund 1977). Male Atlantic sturgeon Acipenser oxyrinchus also remain longer on the spawning grounds and in the river than do females (Dovel and Berggren 1983; Van Eenennaam et al. 1996).
Although an earlier migration and longer stay on the spawning grounds is documented for males of various species, explanations for this behavior are lacking. A possible explanation is that males respond to a different migration trigger than do females. Baker (1978) proposed that the timing of migration is based on a "migration threshold," and that natural selection favors different influences on the migration threshold of males and females. According to Baker, the male threshold may be influenced by the presence of receptive females, whereas the female threshold may be physiological and linked to egg maturation. Results for Atlantic sturgeon appear to be consistent with that hypothesis. Van Eenennaam et al. (1996) reported that male Atlantic sturgeon were always present on the spawning grounds during the spawning season but that they increased in number whenever a ripe female moved onto the spawning grounds. For striped bass, we observed considerable variation in the timing of migration among individuals. We hypothesize that individual females might migrate according to their ripeness and that male migration might be related to the upstream movement of nearby ripe females. Cues for spawning ground departure might also vary by sex. Females might be impelled to leave soon after spawning, whereas males may remain as long as ripe females are pres- 

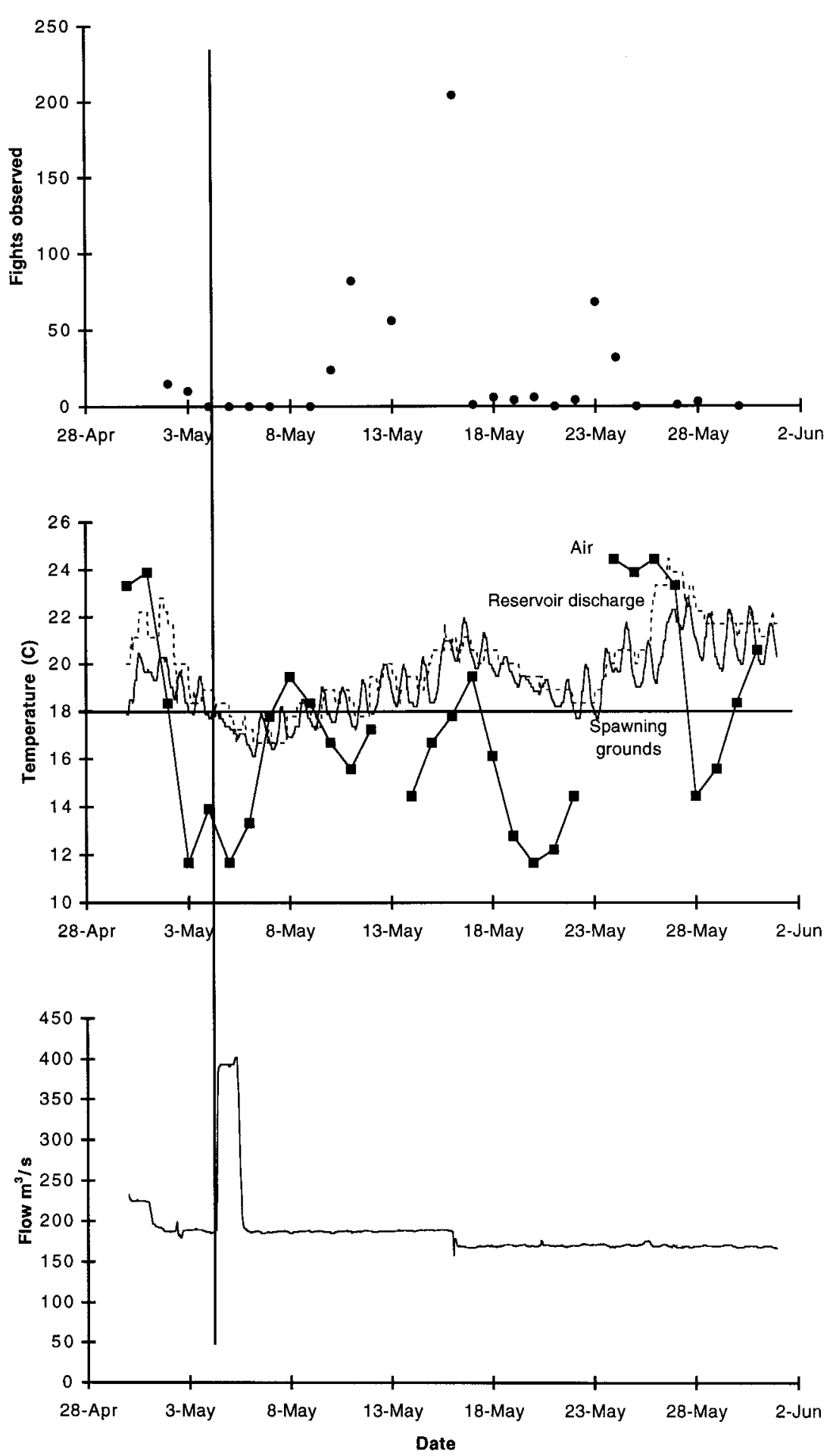

FIGURE 6.-Daily spawning fight counts, daily mean air temperature (squares) along with hourly water temperatures for Roanoke Rapids dam discharges (broken lines) and for spawning grounds (continuous lines), and hourly flows during spring 1994 in the Roanoke River near Weldon, North Carolina. Vertical reference line indicates timing of the controlled flow experiment. The horizontal reference line in panel 2 indicates $18^{\circ} \mathrm{C}$. 
ent. Dovel and Berggren (1983) suggested that female Atlantic sturgeon may be on the spawning grounds for only a few minutes to a few hours, during which time they deposit eggs intermittently.

There are several management implications of the sex-based differences in migratory behavior observed for striped bass. An intensive fishery operates on the Roanoke River spawning grounds, and catch-and-release fishing is substantial when creel limits are reached and after the season closes (Nelson 1991). Our telemetry results showed that individual male striped bass stay longer on the spawning grounds than do individual females. Thus, males would have a greater likelihood of both fishing and hooking mortality. The differences in migratory behavior will also bias survey estimates of abundance that could be used in stock assessment. For example, catches of striped bass on the spawning grounds typically range from 60 to $90 \%$ males (Merriman 1941; Trent and Hassler 1968; Kornegay 1997). Males occur in greater numbers in part because they mature and migrate at a younger age (Olsen and Rulifson 1992). Our results indicate that the sex ratio will also be affected by the tendancy of males to arrive earlier and stay longer on the spawning grounds. A trend in the sex ratio also occurs over the spawning season, the percentage of females increasing from mid-April until sometime in May and then declining (Kornegay and Nelson 1995; Kornegay 1997). Kornegay (1997) attributed this pattern to the delayed migration and shorter residency time on the spawning grounds that Carmichael (1995) reported for telemetered females.

The shorter residency time for individual females not only affects the sex ratio of catches, it introduces bias in survey catch-per-unit-effort (CPUE) data. At peak abundance, our results indicate that all the migrating males but only half the migrating females are on the spawning grounds at a particular time. The CPUE data would not account for the movements of individual females in and out of the study area during the spawning season. Capture-recapture or telemetry methods could be used to account for such movements (Pollock et al. 1990; White and Garrott 1990).

We also found evidence that telemetry data could be used to estimate losses due to poaching. Within the Roanoke River, the recreational season closes during the spawning season once a preset quota is reached; thus many fish remain within the river after the closure. We documented through use of the receiving stations and manual searching that 2 of 43 fish entering the river during 1994 and
1995 were lost while migrating upriver after the season had closed. The fish that disappeared during the 1994 migration was likely harvested, though its transmitter could have failed. The fish harvested during the 1995 migration was reported to have been caught while the season was open, but our telemetry data document that the fish was alive and swimming upriver after the season had closed.

The fish in our study exhibited only localized movements on the spawning grounds (Carmichael 1995). This differs from the results of a study in several Chesapeake Bay tributaries, wherein fish moved daily between the spawning grounds and an estuarine area about $20 \mathrm{~km}$ downriver. Hocutt et al. (1990) proposed that Chesapeake Bay fish returned to brackish water for osmoregulatory purposes. Roanoke River fish must adapt to freshwater during their migration, because over $250 \mathrm{~km}$ separates the spawning grounds from brackish water.

We did not observe any notable changes in the distribution of striped bass on the spawning grounds in response to either a short-term (natural) decrease in temperature or an (experimental) increase in flow. The temperature change that we observed was greater than that observed during a natural storm in 1989 , but it was short-lived because flows were relatively low and air temperature soon returned to more typical May levels. Spawning activity began again within a few days once water temperatures increased above $18^{\circ} \mathrm{C}$. Our flow experiment resulted in only a moderate change of short duration (from about 190 to 390 $\mathrm{m}^{3} / \mathrm{s}$ over $1 \mathrm{~d}$ ), and did not cause a noticeable drop in temperature. The storm in May 1989 caused flow to increase from about 170 to $566 \mathrm{~m}^{3} / \mathrm{s}$ over a 2-day period and remain at that level for $27 \mathrm{~d}$ (Rulifson and Manooch 1990b). The resulting drop in water temperature caused spawning to halt for several weeks (Rulifson 1991). To fully evaluate the effects on the movements of spawning fish, further studies involving reservoir releases of greater magnitude and longer duration at various times during the spawning season would be necessary.

\section{Acknowledgments}

We thank W. Laney, W. Cole, and E. Atstupenas (U.S. Fish and Wildlife Service); K. Nelson, J. Kornegay, F. McBride, and A. Little (North Carolina Wildlife Resources Commission); S. Taylor, L. Henry, and S. Winslow (North Carolina Division of Marine Fisheries); and R. Rulifson (East Carolina University) for their invaluable assistance during this study. We also thank the many 
graduate and undergraduate students who assisted in the field, particularly M. Hedrick who conducted the 1995 monitoring work. M. Stoskopf and C. Sullivan provided instruction in fish surgery. G. Gurley of North Carolina Power provided temperature data, and J. Bales of the U.S. Geological Survey provided discharge data. We thank Mr. Gaylord, Mr. Winslow, Mr. McLennon, and Mr. Birdsong for allowing access to their properties. Funding for this project was provided by the U.S. Fish and Wildlife Service and the North Carolina Wildlife Resources Commission.

\section{References}

Baker, R. R. 1978. The evolutionary ecology of animal migration. Holmes and Meier, New York.

Carmichael, J. T. 1995. Effects of flow and temperature on spawning and migratory behavior of Albemarle Sound-Roanoke River striped bass. Master's thesis. North Carolina State University, Raleigh.

Chadwick, H. K. 1967. Recent migrations of the Sacramento-San Joaquin River striped bass population. Transactions of the American Fisheries Society 96: 327-342.

Chittenden, M. E., Jr. 1975. Dynamics of American shad, Alosa sapidissima, runs in the Delaware River. Fishery Bulletin 73:487-494.

Coe, J. L. 1964. The formative cultures of the Carolina Piedmont. Transactions of the American Philosophical Society 54 (part 5).

Dorazio, R. M. 1995. Mortality estimates of striped bass caught in Albemarle Sound and Roanoke River, North Carolina. North American Journal of Fisheries Management 15:290-299.

Dovel, W. L., and T. J. Berggren. 1983. Atlantic sturgeon of the Hudson estuary, New York. New York Fish and Game Journal 30:140-172.

Earley, L. S., and T. Dossett. 1996. Sterling Keeter's River. Wildlife in North Carolina (May):9-11.

Giese, G. L., H. B. Wilder, and G. G. Parker, Jr. 1985. Hydrology of major estuaries and sounds of North Carolina. U.S. Geological Survey Water-Supply Paper 2221.

Gilbert, C. R. 1992. Rare and endangered biota of Florida. Volume II. Fishes. University Press of Florida, Gainesville.

Gray, R. H., and J. M. Haynes. 1979. Spawning migration of adult chinook salmon (Oncorhynchus tshawaytscha) carrying external and internal radio transmitters. Journal of the Fisheries Research Board of Canada 36:1060-1064.

Haeseker, S. L., J. T. Carmichael, and J. E. Hightower. 1996. Summer distribution and condition of striped bass within Albemarle Sound, North Carolina. Transactions of the American Fisheries Society 125: 690-704

Hall, J. W., T. I. J. Smith, and S. D. Lamprecht. 1991. Movements and habitats of shortnose sturgeon, Acipenser brevirostrum in the Savannah River. Copeia 1991:695-702.
Hart, L. G., and R. C. Summerfelt. 1975. Surgical procedures for implanting ultrasonic transmitters into flathead catfish (Pylodictis olivaris). Transactions of the American Fisheries Society 104:56-59.

Hasler, A. D., R. M. Horall, and W. Braemer. 1958. Sunorientation and homing in fishes. Limnology and Oceanography 3:353-361.

Hassler, W. W., N. L. Hill, and J. T. Brown. 1981. The status and abundance of striped bass, Morone saxatilis, in the Roanoke River and Albemarle Sound, North Carolina, 1956-1980. North Carolina Department of Natural Resources and Community Development, Division of Marine Fisheries, Special Scientific Report 38, Morehead City.

Henry, L. T., H. C. Hardy, and S. D. Taylor. 1992. Fishery independent gill net survey for Albemarle Sound striped bass: a characterization of the Albemarle/Roanoke population. Report to North Carolina Striped Bass Study Management Board, Project 91-01, North Carolina Division of Marine Fisheries, Morehead City.

Henry, L. T., and S. D. Taylor. 1991. Juvenile abundance index of young-of-year striped bass 19881990. NOAA Technical Memorandum NMFSSEFC-291:202-210.

Hocutt, C. H., S. E. Seibold, R. M. Harrell, R. V. Jesien, and W. H. Bason. 1990. Behavioral observations of striped bass (Morone saxatilis) on the spawning grounds of the Choptank and Nanticoke rivers, Maryland, USA. Journal of Applied Ichthyology 6: 211-222.

Holland, B. F., Jr., and G. F. Yelverton. 1973. Distribution and biological studies of anadromous fishes offshore North Carolina. North Carolina Division of Commercial and Sports Fisheries, Special Scientific Report 24, Raleigh.

Jenkins, R. E., and N. M. Burkhead. 1994. Freshwater fishes of Virginia. American Fisheries Society, Bethesda, Maryland.

Koopmans, L. H. 1981. Introduction to contemporary statistical methods. Duxbury Press, Boston.

Kornegay, J. W. 1997. Assessment of the striped bass spawning stock in Roanoke River, North Carolina, 1995-1996. North Carolina Wildlife Resources Commission, Federal Aid in Sport Fish Restoration Project F-22, Final Report, Raleigh.

Kornegay, J. W., and K. L. Nelson. 1995. Assessment of the striped bass spawning stock in Roanoke River, North Carolina, 1993-1994. North Carolina Wildlife Resources Commission, Federal Aid in Sport Fish Restoration, Project F-22, Final report, Raleigh.

Loesch, J. G., and W. A. Lund. 1977. A contribution to the life history of the blueback herring, Alosa aestivalis. Transactions of the American Fisheries Society 106:583-589.

Manooch, C. S. III, and R. A. Rulifson. 1989. Roanoke River Water Flow Committee report: a recommended water flow regime for the Roanoke River, North Carolina, to benefit anadromous striped bass and other below-dam resources and users. NOAA Technical Memorandum NMFS-SEFC-216. 
Mansueti, R. J. 1961. Age, growth, and movements of the striped bass, Roccus saxatilis, taken in size selective fishing gear in Maryland. Chesapeake Science $2: 9-36$

McLaren, J. B., J. C. Cooper, J. B. Hoff, and V. Lander. 1981. Movements of Hudson River striped bass. Transactions of the American Fisheries Society 110: $158-167$.

Merriman, D. 1941. Studies on the striped bass (Roccus saxatilis) of the Atlantic coast. U.S. Fish and Wildlife Service Fishery Bulletin 50(35).

Moser, M. L., and S. W. Ross. 1995. Habitat use and movements of shortnose and Atlantic sturgeons in the lower Cape Fear River, North Carolina. Transactions of the American Fisheries Society 124:225234.

Nelson, K. L. 1991. Roanoke River sport fishery creel survey, spring 1989-1990. North Carolina Wildlife Resources Commission, Coastal Fisheries Investigations, Federal Aid in Sport Fish Restoration, Project F-22-R, Final Report, Raleigh.

Olsen, E. J., and R. A. Rulifson. 1992. Maturation and fecundity of Roanoke River-Albemarle Sound striped bass. Transactions of the American Fisheries Society 121:524-537.

Pollock, K. H., J. D. Nichols, C. Brownie, and J. E. Hines. 1990. Statistical inference for capture-recapture experiments. Wildlife Monographs 107.

Ross, R. M., T. W. H. Backman, and R. M. Bennett. 1994. Evaluation of habitat suitability index models for riverine life stages of American shad, with proposed models for premigratory juveniles. U.S. Fish and Wildlife Service Biological Report 14.

Rulifson, R. A. 1991. Striped bass spawning activity and reservoir discharge. NOAA Technical Memorandum NMFS-SEFC 291:194-201.

Rulfison, R. A. 1992. Striped bass egg abundance and viability at Scotland Neck, Roanoke River, North Carolina for 1991. North Carolina Wildlife Resources Commission, Federal Aid in Sport Fish Restoration, Project F-27, Study 2, Completion Report, Raleigh.

Rulifson, R. A., and five coauthors. 1992. Food and feeding of young striped bass in Roanoke River and western Albemarle Sound, North Carolina, 1984-
1991. North Carolina Wildlife Resources Commission, Federal Aid in Sport Fish Restoration, Project F-27, Completion Report, Raleigh.

Rulifson, R. A., J. J. Isely, and C. S. Manooch III. 1993. Age, growth, and survival of juvenile striped bass determined by counting daily growth rings on otoliths, 1990-1992. Pages 226-238 in R. A. Rulifson and C. S. Manooch III, editors. Roanoke River Water Flow Committee report for 1991-1993. Albemarle-Pamlico estuarine study, Project APES 9318, Raleigh, North Carolina.

Rulifson, R. A., and C. S. Manooch III. 1990a. Recruitment of juvenile striped bass in the Roanoke River, North Carolina, as related to reservoir discharge. North American Journal of Fisheries Management 10:397-407.

Rulifson, R. A., and C. S. Manooch III, editors. 1990 b. Roanoke River Water Flow Committee report for 1988 and 1989. NOAA Technical Memorandum NMFS-SEFC-256.

Smith, H. M. 1907. The fishes of North Carolina. North Carolina Geological and Economic Survey 2.

Stevenson, C. H. 1897. The restricted inland range of shad due to artificial obstructions and its effect on natural reproduction. U.S. Fish Commission Bulletin 17:265-271.

Trent, L., and W. H. Hassler. 1968. Gill net selection, migration, size and age composition, sex ratio, harvest efficiency, and management of striped bass in the Roanoke River, North Carolina. Chesapeake Science 9:217-232.

USFWS (U.S. Fish and Wildlife Service). 1992. Report to Congress for the North Carolina striped bass study. Albemarle Sound and Roanoke River basin. USFWS, Morehead City, North Carolina.

Van Eenennaam, J. P., and five coauthors. 1996. Reproductive condition of the Atlantic sturgeon (Acipenser oxyrinchus) in the Hudson River. Estuaries 19:769-777.

White, G. C., and R. A. Garrott. 1990. Analysis of wildlife radio-tracking data. Academic Press, San Diego, California.

Received June 26, 1996 Accepted October 2, 1997 